\title{
Optimisation of Free Fatty Acid Removal in Nyamplung Seed Oil (Callophyllum inophyllum L.) using Response Surface Methodology Analysis
}

\author{
Ratna Dewi Kusumaningtyas ${ }^{1 *}$, Haniif Prasetiawan ${ }^{1}$, Radenrara Dewi Artanti \\ Putri $^{1}$, Bayu Triwibowo ${ }^{1}$, Siti Choirunisa Furi Kurnita ${ }^{1}$, Nanda Dwi Anggraeni ${ }^{1}$, \\ Harumi Veny ${ }^{2}$, Fazlena Hamzah ${ }^{2}$ and Miradatul Najwa Muhd Rodhi ${ }^{2}$ \\ ${ }^{1}$ Chemical Engineering Department, Faculty of Engineering, Universitas Negeri Semarang, Kampus Sekaran, \\ Gunungpati, Semarang 50229, Indonesia \\ ${ }^{2}$ School of Chemical Engineering, College of Engineering, Universiti Teknologi Mara (UiTM), \\ 40450 Shah Alam, Selangor, Malaysia
}

\begin{abstract}
Nyamplung seed (Calophyllum inophyllum L.) oil is a prospective non-edible vegetable oil as biodiesel feedstock. However, it cannot be directly used in the alkaline catalysed transesterification reaction since it contains high free fatty acid (FFA) of $19.17 \%$. The FFA content above $2 \%$ will cause saponification reaction, reducing the biodiesel yield. In this work, FFA removal was performed using sulfuric acid catalysed esterification to meet the maximum FFA amount of 2\%. Experimental work and response surface methodology (RSM) analysis were conducted. The reaction was conducted at the fixed molar ratio of nyamplung seed oil and methanol of 1:30 and the reaction times of 120 minutes. The

ARTICLE INFO

Article history:

Received: 31 March 2021

Accepted: 15 July 2021

Published: 08 October 2021

DOI: https://doi.org/10.47836/pjst.29.4.20

E-mail addresses:

ratnadewi.kusumaningtyas@mail.unnes.ac.id (Ratna Dewi Kusumaningtyas)

haniif.prasetiawan@mail.unnes.ac.id (Haniif Prasetiawan) dewi.artanti@mail.unnes.ac.id (Radenrara Dewi Artanti Putri) bayu.triwibowo@mail.unnes.ac.id (Bayu Triwibowo) schoirunisafurikurnita@gmail.com (Siti Choirunisa Furi Kurnita) nandadwianggraeni@gmail.com (Nanda Dwi Anggraeni) harumi2244@uitm.edu.my (Harumi Veny) fazlena@salam.uitm.edu.my (Fazlena Hamzah)

miradatul@salam.uitm.edu.my (Miradatul Najwa Muhd Rodhi)

* Corresponding author catalyst concentration and the reaction temperature were varied. The highest reaction conversion was $78.18 \%$, and the FFA concentration was decreased to $4.01 \%$ at the temperature of $60^{\circ} \mathrm{C}$ and reaction time of 120 minutes. The polynomial model analysis on RSM demonstrated that the quadratic model was the most suitable FFA conversion optimisation. The RSM analysis exhibited the optimum FFA conversion of $78.27 \%$ and the FFA content of $4 \%$, attained at the reaction temperature, catalyst concentration, and reaction time of $59.09^{\circ} \mathrm{C}$,
\end{abstract}


$1.98 \% \mathrm{~g} / \mathrm{g}$ nyamplung seed oil, and 119.95 minutes, respectively. Extrapolation using RSM predicted that the targeted FFA content of $2 \%$ could be obtained at the temperature, catalyst concentration, and reaction time of $58.97^{\circ} \mathrm{C}, 3 \%$, and 194.9 minutes, respectively, with a fixed molar ratio of oil to methanol of 1:30. The results disclosed that RSM is an appropriate statistical method for optimising the process variable in the esterification reaction to obtain the targeted value of FFA.

Keywords: Biodiesel, Box-Behnken, esterification, FFA, quadratic model, RSM, sulfuric acid

\section{INTRODUCTION}

Population, economic, and industry growth have intensified the global energy demand. To date, fossil energy still dominates the energy supply worldwide (Ghasemian et al., 2020). However, crude oil production in some countries shows a declining trend, which is not in balance with the energy need. Besides, the utilisation of fossil fuel currently also faces an environmental challenge as its combustion becomes the major source of carbon dioxide emission. Carbon dioxide is among the most dominant greenhouse gasses, contributing to global warming and climate change (Paraschiv \& Paraschiv, 2020). The issues on the fossil fuel supply depletion and the negative environmental effect of fossil fuel utilisation have led to the increasing interest in renewable energy research. In recent days, many countries implement the policy to use fossil fuel and biofuel blending to ensure energy sustainability and security. Biodiesel is a viable biofuel that can be used as pure or in blends with diesel fuel. This alternative fuel is prospective for large scale production and application since it is non-toxic, low sulfur and aromatics content, biodegradable, and simple to use. Moreover, it holds neutral carbon characteristics, a high flash point that ensures safety in handling and storage, good lubricity, and high oxygen (Corach et al., 2017; Dey et al., 2021). Application of biodiesel/diesel fuel blends in diesel engines shows a good combustion, performance and emission reduction, especially for B20 or $20 \%$ biodiesel in the biodiesel-diesel fuel mixture (Mubarak et al., 2021).

Biodiesel is a fatty acid methyl ester derived from vegetable oils and/or animal fats. Most of the current industrial production of biodiesel from vegetable oils is achieved through transesterification (Aboelazayem et al., 2018; Demirbas, 2006). Theoretically, in transesterification, at least three moles of alcohol are required to achieve complete conversion of one mol of triglycerides to alkyl esters (Islam et al., 2014). The most common catalyst for biodiesel production is an alkaline catalyst such as $\mathrm{KOH}, \mathrm{NaOH}$, or solid base catalyst. The transesterification process using an alkaline catalyst is cheap and easy.

Some potential biodiesel feedstocks in Indonesia are crude palm oil, jatropha oil, and coconut oil. However, currently, the non-edible vegetable oil is preferred as biodiesel raw material to avoid the conflict between food and energy need (Kusumaningtyas et al., 2014). Among Indonesia's the prospective local non-edible oil for biodiesel production 
is nyamplung (Calophyllum inophyllum L.) seed oil (Musta et al., 2017; Silitonga et al., 2014). Calophyllum inophyllum $L$ is extensively planted in Indonesia, and the nyamplung seed oil can be purchased from the local farmers (Ong et al., 2019). In addition, Atabani and César (2014) reported that Calophyllum inophyllum methyl ester blended with diesel fuel (B10 and B20) revealed good properties and good engine performance and emission in diesel machines.

However, crude nyamplung seed oil (CNSO) usually contains gum and high free fatty acid (FFA). A high amount of FFA in the feedstock is not desirable in alkaline catalysed transesterification since it can react with the base catalyst, yielding the soap and diminishing the biodiesel yield. The desired amount of FFA in alkaline-catalyst is less than $0.5 \%$ to less than $3 \% \mathrm{w} / \mathrm{w}$ of oil (Arora et al., 2015). Generally, the maximum tolerable amount of FFA in base-catalysed transesterification is $2 \%$. Thus, a pre-treatment step is necessary to reduce the FFA content in nyamplung seed oil to a maximum level of $2 \%$ prior to transesterification reaction. FFA removal in CNSO can be conducted through an esterification reaction using methanol in the presence of an acid catalyst. There are several types of acid catalysts for FFA esterification. They are categorised into the homogenous acid catalysts, for instance, sulfuric acid, para-toluene sulfonic acid, phosphoric acid, and hydro, and $\mathrm{HCl}$ (Harun et al., 2018; Murad et al., 2018) and the heterogenous ones, such as Amberlyst 15, sulfated zirconia, niobic acid, zeolite, and tin (II) chloride (Banchero \& Gozzelino, 2018; Dal Pozzo et al., 2019; Kusumaningtyas et al., 2014). Homogenous catalyst, particularly sulfuric acid, has been found as an efficient and economic catalyst for FFA esterification both at laboratory and industrial scales (Banani et al., 2015; Chai et al., 2014; Gebremariam \& Marchetti, 2018).

Therefore, sulfuric acid was selected as the catalyst for the FFA removal via the esterification reaction of CNSO oil in this work. The investigation included experimental work and the analysis using response surface methodology (RSM) to determine the optimal operation condition, which yielded the targeted FFA final value of $2 \%$. The final FFA level was aimed at $2 \%$ since it is the maximum acceptable FFA value for the subsequent transesterification reaction to avoid undesired saponification reaction. The work comprised the detailed analysis of several polynomial models on RSM to reveal the most appropriate model for optimisation. The study on the FFA esterification in CNSO in the presence of a sulfuric acid catalyst which involves the comprehensive analysis and selection of the various polynomial models in RSM for process optimisation, has never been reported in the literature.

\section{MATERIALS AND METHODS}

\section{Materials}

The material used in this work were: crude nyamplung seed oil, phosphoric acid (from Merck), methanol (industrial grade, form local supplier), ethanol (analytical grade, from 
Merck), $\mathrm{KOH}$ (analytical grade, from Merck), oxalic acid (analytical grade, from Merck), sulfuric acid (analytical grade, from Merck), distilled water (analytical grade, from a local supplier), and phenolphthalein indicator (analytical grade, from Merck).

\section{Nyampung Seed Oil Characterisation}

Prior to the esterification reaction, the crude nyamplung seed oil was first degummed using phosphoric acid to remove its gum content, resulting in refined nyamplung seed oil (RNSO). Both CNSO and RNSO were then characterised to reveal their properties. First, the fatty acid composition was determined using Gas Chromatography-Mass Spectroscopy (GC-MS Perkin Elmer, GC Clarus 680, MS Clarus SQ 8T), similar to our previous work (Kusumaningtyas et al., 2016). Next, density measurement was conducted using a pycnometer (Taghizade, 2016). Then, viscosity determination was carried out using viscometer bath Stanhope-Seta KV6 tube 350 CFO. Finally, acid value tests were accomplished based on the AOCS acid-base titration method (Banchero \& Gozzelino, 2018).

\section{Degumming}

Initially, $500 \mathrm{ml} \mathrm{CNSO}$ was introduced into $500 \mathrm{~mL}$ beaker glass and heated using a hot plate at $70^{\circ} \mathrm{C}$. Next, sulfuric acid with a concentration of $0.3 \% \mathrm{w} / \mathrm{w}$ was added. The mixing was kept for 25 minutes using a magnetic stirrer to ensure the completion of the degumming reaction. After the reaction finished, the $\mathrm{CNSO}$ was inputted into the separating funnel and added with warm distilled water $\left(40-50^{\circ} \mathrm{C}\right.$ in temperature) for purification. The mixture of the degummed CNSO and water was settled for 24 hours until the gum was separated. Then, the two layers were formed. The top and bottom layers were refined nyamplung seed oil (RNSO) and gum, respectively. To remove the water content, the RNSO was then heated using the oven at $105^{\circ} \mathrm{C}$ until it reached the constant weight.

\section{FFA Removal}

The FFA removal was conducted via an esterification reaction with methanol employing sulfuric acid. First, RNSO and methanol were weighed to obtain the molar ratio of RNSO and methanol of 1:30. Then, RNSO was introduced into the three necks flask batch reactor and heated until it reached the reaction temperature. On the other flask, methanol was also heated at an exact temperature. When both RNSO and methanol attained the reaction temperature, methanol was then poured into the reactor. The reaction temperatures were varied at $40^{\circ} \mathrm{C}, 50^{\circ} \mathrm{C}$, and $60^{\circ} \mathrm{C}$. Afterwards, the sulfuric acid catalyst was added at a specific concentration (1\%, 3\%, 5\%, 7\% w/w RNSO). The reaction was carried out for 120 minutes. A constant mixing using a magnetic stirrer with a speed of $1000 \mathrm{rpm}$ was performed to certify the homogeneous reaction. The total experimental running was 7 
experiments with different operating conditions. The sample was taken periodically every 10 minutes for each experiment. Hence, the total sampling number was 31 times. The reaction conversions were calculated based on the FFA content of the sample using the procedure of our previous work. The FFA content of the samples was calculated using the standard KOH titration (Kusumaningtyas et al., 2018).

\section{RSM}

RSM using Design Expert 11 software was employed for statistical calculation using three different variables (reaction temperature, catalyst concentration, and reaction time) based on the Box-Behnken methodology (BBD). The four polynomials models in the RSM, namely linear, interactive (2FI), quadratic, and cubic, were evaluated to determine the most appropriate model for optimisation. The selected model was applied in this work.

\section{RESULT AND DISCUSSION \\ CNSO and RNSO Characterization}

The properties of CNSO and refined nyamplung seed oil (RNSO), which has undergone a degumming process, were demonstrated in Table 1. The degumming process aims for reducing the gum content. Besides, degumming has also brought about a better characteristic of the oil feedstock. It can be observed in Table 1, the density viscosity, acid number, and acidity of the RNSO were lower than CNSO. The decreasing value of density happened due to the losses of some heavy compounds such as gum. The degumming process also caused a lighter colour of the oil. It was due to removing the compounds which significantly affected the oil colour (Lamas et al., 2016). Thus, the degumming process has shown a better characteristic of the oil feedstock, leading to an effective transesterification reaction and a higher quality of biodiesel product.

Table 1

Properties of CNSO and RNSO

\begin{tabular}{lcc}
\hline Properties & CNSO (Before Degumming) & RNSO (After Degumming) \\
\hline Density $\left(\mathrm{kg} / \mathrm{m}^{3}\right)$ & 906 & 898 \\
Viscosity $\left(\mathrm{mm}^{2} / \mathrm{s}\right)$ & 60.39 & 59.04 \\
Acid Number $(\mathrm{mg} \mathrm{KOH} / \mathrm{g})$ & 0.38 & 0.36 \\
Acidity $(\%)$ & 19.18 & 18.39 \\
\hline
\end{tabular}

The fatty acid composition in CNSO was determined using GC-MS, and the result was exhibited in Table 2. Based on this composition, the molecular weight of CNSO can be calculated. It was found that CNSO molecular weight was $869.74 \mathrm{~g} / \mathrm{mol}$ and the most dominant fatty acid in CNSO were oleic acid and linoleic acids. It is in good agreement with 
the fatty acid composition found by Aparamarta et al. (2020). The fatty acid composition was merely performed for the CNSO. Fatty acid analysis for the RNSO was discounted. Based on the slightly altering of the acid number of CNSO and RNSO exhibited in Table 1 , it can be assumed that the degumming process did not significantly change the fatty acid composition.

Table 2

CNSO fatty acid composition

\begin{tabular}{lcc}
\hline Fatty acid & Molecular Weight $(\mathrm{g} / \mathrm{mol})$ & Area $(\%)$ \\
\hline Palmitic acid & 256.2228 & 15.51 \\
Linoleic acid & 280.45 & 28.94 \\
Oleic acid & 282.52 & 40.55 \\
Stearic acid & 284.47 & 14,39 \\
Arachidic acid & 312.54 & 0.60 \\
\hline
\end{tabular}

\section{Esterification of FFA: Effect of Catalyst Concentration}

FFA removal was conducted via esterification reaction of RNSO and methanol in the presence of a sulfuric acid catalyst. Sulfuric acid catalyst concentration was varied at $1 \%, 3 \%, 5 \%$, and $7 \% \mathrm{w} / \mathrm{w}$ RNSO with the molar ratio of RNSO: methanol of 1: 30 and temperature of $40^{\circ} \mathrm{C}, 50^{\circ} \mathrm{C}$, and $60^{\circ} \mathrm{C}$. Encinar et al. (2021) suggested the sulfuric acid catalyst concentration of $0.5 \%$ to $2 \%$ for the feedstock with an FFA content of $10.7 \%$. The higher sulfuric catalyst concentration can be employed for the higher acidic vegetable oils. The molar ratio of oil to methanol referred to Chai et al. (2014), recommended the molar ratio of oil to methanol in the range of 1:20 to 1:60. Specifically, Marchetti \& Errazu (2008) proposed the molar ratio of 1:30 as the optimal condition. On the other hand, the reaction temperature ratio was adjusted to the boiling point of the methanol. The reaction was run for 120 minutes, as suggested by Chai et al. (2014). The effect of catalyst concentration on the FFA conversion is demonstrated in Figure 1.

In Figure 1, reaction conversion increased at the catalyst concentration from $1 \%$ to $3 \%$. It was due to the decreasing of the activation energy by the addition of the catalyst. Thus, the collision between the particles was increased, resulting in a higher possibility of reaction occurrence. Accordingly, it enhanced the reaction rate and FFA conversion. On the other hand, the apparent reaction conversion declined on the higher reaction concentration (5\% to $7 \%$ ) since the excessive amount of catalyst could provoke the side reaction and reduce the FFA conversion (Widiarti et al., 2017). The excessive employment of catalysts will correspondingly bring about the difficulty and higher costs in the product separation. Based on the experiments, it was revealed that the optimum catalyst concentration was $3 \%$, which resulted in the FFA conversion of $78.18 \%$ at the temperature of $60^{\circ} \mathrm{C}$ with a reaction time of 120 minutes. The FFA content of such operation conditions was $4.01 \%$. This value 


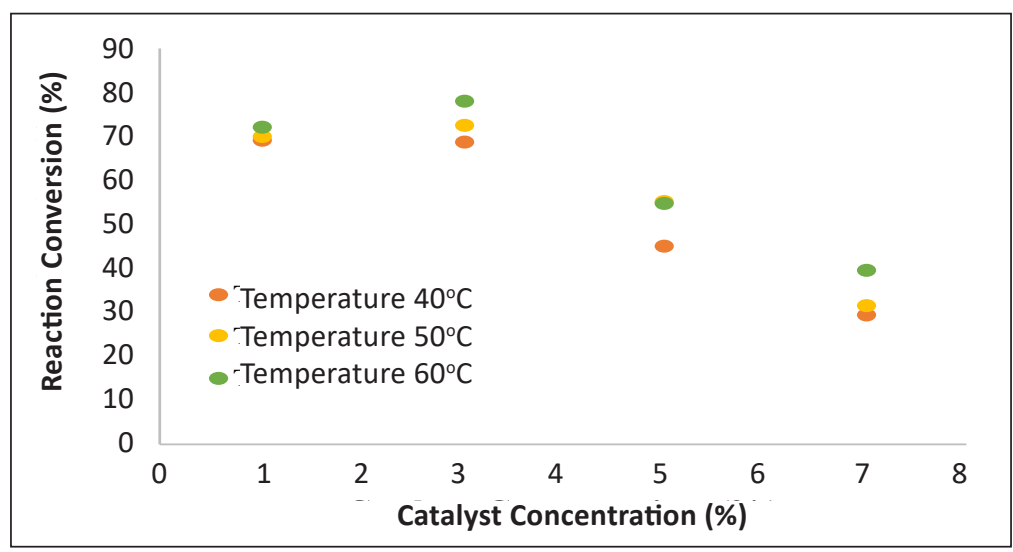

Figure 1. Effect of Catalyst Concentration on the FFA Conversion at the Reaction Time of 120 Minutes and Molar Ratio of RNSO to Methanol of 1:30

has not satisfied the maximum allowable FFA content of $2 \%$ for the transesterification reaction yet. Therefore, further, observation was conducted at different temperatures and reaction times.

\section{Esterification of FFA: Effect of Temperature and Reaction Time}

The influence of the reaction temperature and time was presented in Figure 2. It is shown that the higher the reaction temperature, the higher removal of FFA occurred. This phenomenon was because the higher reaction temperature will increase the molecular motion of each reactant species, improving the kinetics energy. Therefore, the increase in the reaction temperature raised the FFA conversion. This fact also agreed with the Arrhenius law, which states that the reaction rate is equivalent to the reaction temperature. Encinar et al. (2021) described that this phenomenon was common for the endothermic reaction. According to Le Chatelier's principle, the equilibrium shifts to the product formation as the temperature rises.

As shown in Figure 2, it was also found that the FFA conversion enhanced with the reaction time, but the enhancement was slower from 60 to 120 minutes. It means that the reaction was approaching the chemical equilibrium point at 120 minutes. Based on catalyst concentration alteration (Figure 1) as well as the temperature and reaction time variation (Figure 2), it was revealed that the best conversion was achieved at the catalyst concentration of $3 \%$, molar ratio of RNSO to methanol of $1: 30$, reaction temperature of $60^{\circ} \mathrm{C}$, and reaction time of 120 minutes with the FFA conversion of $78.18 \%$ and the FFA content of $4.01 \%$. This result was in line with our previous work that reported that the optimum condition of FFA removal in kapok randu seed oil using methanol reactant and the sulfuric acid catalyst was $60^{\circ} \mathrm{C}$, and reaction time of 120 minutes (Kusumaningtyas et al., 2019). The promising way to enhance the reaction conversion is by increasing the reaction 


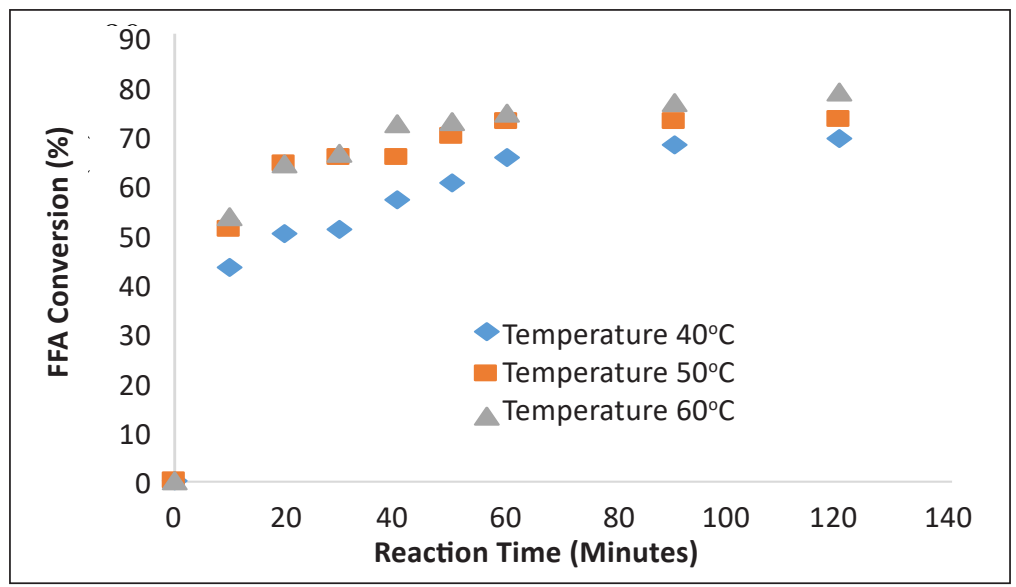

Figure 2. Effect of Temperature and Reaction Time on the FFA Conversion at the Catalyst Concentration of 3\% w/w and Molar Ratio of RNSO and Methanol of 1:30

temperature to $65^{\circ} \mathrm{C}$ and applying a higher molar ratio of the reactants, as accomplished by Chai et al. (2014). In this work, the lowest FFA content obtained among all the experiments conducted was $4.01 \%$. It did not match FFA content's standard limitation for base catalysed transesterification (2\%). Therefore, response surface methodology optimisation was then carried out to predict the optimum operating condition of the esterification reaction, yielding the $2 \%$ FFA content of RNSO.

\section{RSM Analysis}

The result of the FFA removal was under the targeted value of FFA content (maximum $2 \%$ ). Thus, RSM will be beneficial for designing the operating condition to achieve the targeted conversion. RSM is a set of mathematical and statistical tools that can be used to develop an empirical model that correlates the reaction conversion or product yield with the significant process parameters (Veljković et al., 2019). The application of this tool is valuable to reduce the experimental cost (Liu et al., 2018). However, there are several models provided for optimisation using RSM. Hence, a suitable model should be selected. In this work, four polynomial models (linear, interactive or 2FI, quadratic, and cubic) in RSM were evaluated to determine the most suitable model which fitted the experimental data. Similar models were also tested by Maran \& Priya (2015) and Ahmad et al. (2020).

In this study, the best polynomial model will be useful for future work to design the experiment condition and improve the conversion of the reaction. A combination of the effects of the 3 independent variables (catalyst concentration, temperature, and reaction time) on the FFA esterification in RNSO using sulfuric acid catalyst were investigated to select the model. These variables were used to optimise using RSM since they were the main parameters studied in experimental work. Experiments with the different combinations 
of the three variables were conducted and calculated statistically using an experimental design based on the Box-Behnken Methodology (BBD). The BBD is a self-reliant quadratic design which does not involve implanted factorial (Rodríguez-Ramírez et al., 2020). This complete factorial design is the most commonly applied in RSM optimisation (Veljković et al., 2019). The experimental design using BBD is shown in Table 3.

Table 3

Experimental Design Using Box-Behnken Methodology (BBD), which equipped with the experimental data and predictive result

\begin{tabular}{|c|c|c|c|c|c|c|c|c|c|}
\hline \multirow[t]{2}{*}{ Run } & \multirow{2}{*}{$\begin{array}{c}\text { Temperature } \\
\text { (A) }\end{array}$} & \multirow{2}{*}{$\begin{array}{c}\text { Catalyst } \\
\text { Concentration } \\
\text { (B) }\end{array}$} & \multirow{2}{*}{$\begin{array}{l}\text { Time } \\
\text { (C) }\end{array}$} & \multicolumn{2}{|c|}{$\begin{array}{c}\text { FFA Conversion, } \\
\% \\
\end{array}$} & \multirow{2}{*}{$\begin{array}{l}\% \\
\text { Error }\end{array}$} & \multicolumn{2}{|c|}{$\begin{array}{c}\text { FFA Content, } \\
\% \\
\end{array}$} & \multirow{2}{*}{$\begin{array}{l}\% \\
\text { Error }\end{array}$} \\
\hline & & & & Exp & Prediction & & Exp & Prediction & \\
\hline 1 & 60 & 3 & 60 & 74.07 & 74.10 & 0.05 & 4.77 & 4.97 & 4.25 \\
\hline 2 & 60 & 3 & 120 & 78.18 & 78.75 & 0.73 & 4.02 & 4.24 & 5.46 \\
\hline 3 & 40 & 3 & 60 & 64.9 & 66.67 & 2.73 & 6.46 & 6.30 & 2.52 \\
\hline 4 & 50 & 5 & 120 & 55.41 & 56.88 & 2.65 & 8.21 & 8.44 & 2.76 \\
\hline 5 & 40 & 3 & 120 & 68.7 & 71.00 & 3.35 & 5.76 & 5.61 & 2.53 \\
\hline 6 & 40 & 5 & 90 & 44.97 & 47.97 & 6.67 & 10.13 & 9.94 & 1.88 \\
\hline 7 & 60 & 5 & 90 & 52.56 & 56.84 & 8.14 & 8.73 & 8.35 & 4.30 \\
\hline 8 & 50 & 1 & 120 & 69.96 & 72.15 & 3.13 & 5.53 & 5.22 & 5.66 \\
\hline 9 & 40 & 1 & 90 & 66.8 & 64.84 & 2.94 & 6.11 & 6.54 & 7.10 \\
\hline 10 & 50 & 5 & 60 & 52.56 & 52.08 & 0.91 & 8.73 & 9.09 & 4.07 \\
\hline 11 & 60 & 1 & 90 & 71.85 & 71.14 & 0.98 & 5.18 & 5.43 & 4.83 \\
\hline 12 & 50 & 3 & 90 & 72.17 & 73.36 & 1.64 & 5.12 & 5.15 & 0.53 \\
\hline 13 & 50 & 1 & 60 & 66.48 & 67.98 & 2.25 & 6.17 & 5.99 & 3.00 \\
\hline
\end{tabular}

The four polynomial models, namely linear, interactive (2FI), quadratic, and cubic, were used to predict the response variable to the experimental data. In addition, two types of tests, i.e., a sequential model sum of squares and model summary, were used as the basis for the polynomial model determination, which is suitable for optimising the FFA conversion. The result is shown in Tables 4 and 5, respectively.

Based on the result shown in Tables 4 and 5, it was acquired that the quadratic model was justified as the most suitable model for optimising the FFA content and conversion in the esterification using a sulfuric acid catalyst. The basis of the selection of the quadratic model was the lowest $\mathrm{p}$-value, the highest value of adjusted $\mathrm{R}^{2}$, and the highest value of predicted $\mathrm{R}^{2}$. Table 4 reveals that the quadratic model provided the lowest p-value. Table 5 shows that the quadratic model provided the highest value of adjusted $\mathrm{R}^{2}$. Meanwhile, the predicted $\mathrm{R}^{2}$ for the quadratic model did not appear in Table 5 since the value was precisely closed to 1 . In contrast, the actual $\mathrm{R}^{2}$ were not presented in Table 5 since this table depicted the summary of the model test. Therefore, the actual $\mathrm{R}^{2}$ values were advanced investigated based on the values of predicted $\mathrm{R}^{2}$. Based on the values of the $\mathrm{p}$-value, adjusted $\mathrm{R}^{2}$, and 
Ratna Dewi Kusumaningtyas, Haniif Prasetiawan, Radenrara Dewi Artanti Putri, Bayu Triwibowo, Siti Choirunisa Furi Kurnita, Nanda Dwi Anggraeni, Harumi Veny, Fazlena Hamzah and Miradatul Najwa Muhd Rodhi

Table 4

Sequential model sum of squares test

\begin{tabular}{|c|c|c|c|c|c|c|}
\hline Component & Sum of square & $\mathrm{DF}$ & Mean Square & F-value & p-value & Remarks \\
\hline \multicolumn{7}{|c|}{ Sequential Sum of Square for FFA Content } \\
\hline Mean & 554.72 & 1 & 554.72 & & & \\
\hline Linear & 25.51 & 3 & 8.50 & 5.08 & 0.0250 & Suggested \\
\hline $2 \mathrm{FI}$ & 0.0595 & 3 & 0.0198 & 0.0079 & 0.9989 & \\
\hline Quadratic & 14.16 & 3 & 4.72 & 16.85 & 0.0221 & Suggested \\
\hline Cubic & 0.8404 & 3 & 0.2801 & & & Aliased \\
\hline Residual & 0.0000 & 0 & & & & \\
\hline Total & 595.30 & 13 & 45.79 & & & \\
\hline \multicolumn{7}{|c|}{ Sequential sum of square for FFA Conversion } \\
\hline Mean & 54097.44 & 1 & 54097.44 & & & \\
\hline Linear & 753.08 & 3 & 251.03 & 5.08 & 0.0249 & Suggested \\
\hline $2 \mathrm{FI}$ & 1.74 & 3 & 0.5787 & 0.0078 & 0.9989 & \\
\hline Quadratic & 417.93 & 3 & 139.31 & 16.83 & 0.0222 & Suggested \\
\hline Cubic & 24.83 & 3 & 8.28 & & & Aliased \\
\hline Residual & 0.0000 & 0 & & & & \\
\hline Total & 55295.02 & 13 & 4253.46 & & & \\
\hline
\end{tabular}

Table 5

Model summary test

\begin{tabular}{|c|c|c|c|c|c|}
\hline Component & Std. Dev & Adjusted $\mathrm{R}^{2}$ & Predicted $\mathrm{R}^{2}$ & Press & Remarks \\
\hline \multicolumn{6}{|c|}{ Model Summary of FFA Content } \\
\hline Linear & 0.0250 & 0.5050 & 0.2313 & Suggested & 0.0250 \\
\hline $2 \mathrm{FI}$ & 0.9989 & 0.2604 & -0.8490 & - & 0.9989 \\
\hline Quadratic & 0.0221 & 0.9172 & - & Suggested & 0.0221 \\
\hline Cubic & - & - & - & Aliased & - \\
\hline \multicolumn{6}{|c|}{ Model summary of FFA Conversion } \\
\hline Linear & 0.0249 & 0.5051 & 0.2314 & Suggested & 0.0249 \\
\hline $2 \mathrm{FI}$ & 0.9989 & 0.2606 & -0.8492 & - & 0.9989 \\
\hline Quadratic & 0.0222 & 0.9171 & - & Suggested & 0.0222 \\
\hline Cubic & - & - & - & Aliased & - \\
\hline
\end{tabular}

predicted $\mathrm{R}^{2}$ attained, the quadratic model was found the most suitable model and further analysed using ANOVA. This finding is in line with the result analysis of Maran \& Priya (2015), which suggested that the quadratic model was the most appropriate.

The empirical model, expressed using the quadratic model with the interaction obtained from the experimental data based on the RSM, was modified into a polynomial equation. The final equation for FFA content and FFA conversion optimisation is presented in Equations 1 and 2, respectively. 
FFA Content $(\%)=16.5-0.306 \mathrm{~A}-2.2 \mathrm{~B}+0.014 \mathrm{C}-0.0059 \mathrm{AB}-0.000042$

$\mathrm{AC}+0.0005 \mathrm{BC}+0.0026 \mathrm{~A}^{2}+0.54 \mathrm{~B}^{2}-0.00014 \mathrm{C}^{2}$

FFA Conversion $(\%)=10.63+1.66 \mathrm{~A}+11.91 \mathrm{~B}-0.081 \mathrm{C}+0.032 \mathrm{AB}+$

$0.00026 \mathrm{AC}+0.0026 \mathrm{BC}-0.014 \mathrm{~A}^{2}-2.94 \mathrm{~B}^{2}+0.00075 \mathrm{C}^{2}$

Statistical analysis for the quadratic model using ANOVA regression model is shown in Table 6.

Table 6

ANOVA regression model to predict the FFA conversion using sulfuric acid catalyst

\begin{tabular}{|c|c|c|c|c|c|c|}
\hline Source & Sum of square & Degree of Freedom & Mean square & F value & p-value & Remarks \\
\hline \multicolumn{7}{|c|}{ ANOVA for FFA Content } \\
\hline Model & 39.73 & 9 & 4.41 & 15.76 & 0.0221 & significant \\
\hline $\mathrm{X}_{1}$ & 4.15 & 1 & 4.15 & 14.80 & 0.0310 & \\
\hline $\mathrm{X}_{2}$ & 20.51 & 1 & 20.51 & 73.22 & 0.0034 & \\
\hline $\mathrm{X}_{3}$ & 0.8515 & 1 & 0.8515 & 3.04 & 0.1796 & \\
\hline $\mathrm{X}_{12}$ & 0.0552 & 1 & 0.0552 & 0.1971 & 0.6871 & \\
\hline $\mathrm{X}_{13}$ & 0.0006 & 1 & 0.0006 & 0.0022 & 0.9653 & \\
\hline $\mathrm{X}_{23}$ & 0.0036 & 1 & 0.0036 & 0.0129 & 0.9169 & \\
\hline $\mathrm{X}_{1}^{2}$ & 0.1486 & 1 & 0.1486 & 0.5306 & 0.5191 & \\
\hline $\mathrm{X}_{2}^{2}$ & 10.69 & 1 & 10.69 & 38.16 & 0.0085 & \\
\hline $\mathrm{X}_{3}^{2}$ & 0.0343 & 1 & 0.0343 & 0.1224 & 0.7495 & \\
\hline Residual & 0.8404 & 3 & 0.2801 & & & \\
\hline Cor Total & 40.57 & 12 & & & & \\
\hline Adeq prec & 12.46 & & & & & \\
\hline \multicolumn{7}{|c|}{ ANOVA for FFA Conversion } \\
\hline Model & 1172.75 & 9 & 130.31 & 15.74 & 0.0222 & significant \\
\hline $\mathrm{X}_{1}$ & 122.38 & 1 & 122.38 & 14.79 & 0.0310 & \\
\hline $\mathrm{X}_{2}$ & 605.35 & 1 & 605.35 & 73.14 & 0.0034 & \\
\hline $\mathrm{X}_{3}$ & 25.35 & 1 & 25.35 & 3.06 & 0.1784 & \\
\hline $\mathrm{X}_{12}$ & 1.61 & 1 & 1.61 & 0.1949 & 0.6888 & \\
\hline $\mathrm{X}_{13}$ & 0.0240 & 1 & 0.0240 & 0.0029 & 0.9604 & \\
\hline $\mathrm{X}_{23}$ & 0.0992 & 1 & 0.0992 & 0.0120 & 0.9197 & \\
\hline $\mathrm{X}_{1}^{2}$ & 4.37 & 1 & 4.37 & 0.5278 & 0.5201 & \\
\hline $\mathrm{X}_{2}^{2}$ & 315.17 & 1 & 315.17 & 38.08 & 0.0086 & \\
\hline $\mathrm{X}_{3}^{2}$ & 1.04 & 1 & 1.04 & 0.1258 & 0.7463 & \\
\hline Residual & 24.83 & 3 & 8.28 & & & \\
\hline Cor Total & 1197.58 & 12 & & & & \\
\hline Adeq prec & 12.46 & & & & & \\
\hline
\end{tabular}


The F-value of the model was 15.76 , indicating that the model was significant. There was only $2.22 \%$ of noise potential, which could cause the model unsuccessful in predicting the value of the response variable (FFA conversion). The p-value was $0.022(<0.05)$, designating that the variables were significant to the model. In this study, the influential variables were $\mathrm{A}, \mathrm{B}$, and $\mathrm{B}^{2}$. Table 6 also demonstrates the value of adeq precision. Adeq precision measures the signal ratio to the disturbance (noise), and its value is expected to be higher than 4 . A ratio of 12.46 resulted in this work, denoted that the inputted signal was appropriate.

Validation of the model capability in predicting is necessary to ensure the accuracy of the model approach. Figure 3 shows the model validation by comparing the predicted result with the experimental data. Figure 3(a) demonstrates that the predictive value based on the model's calculation was close to the experimental data. It was indicated by the

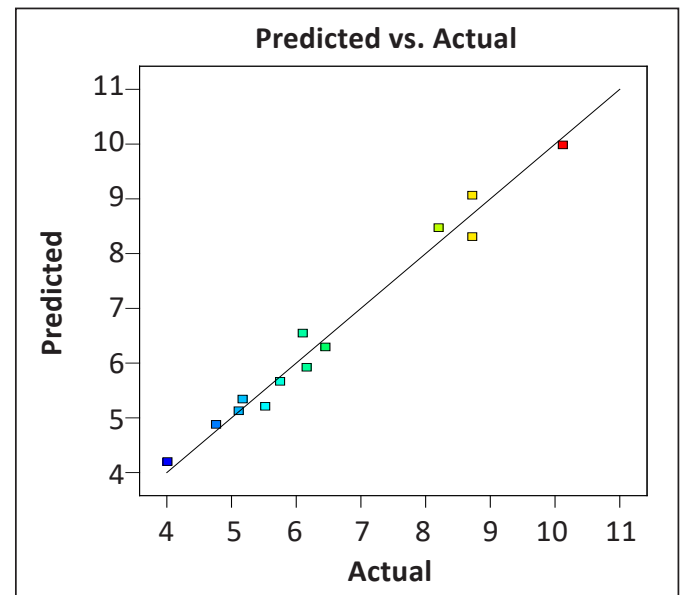

(a)

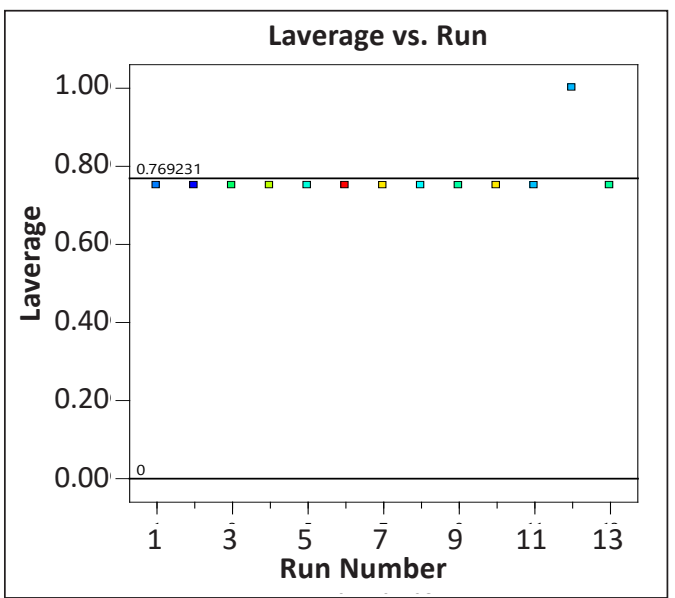

(c)

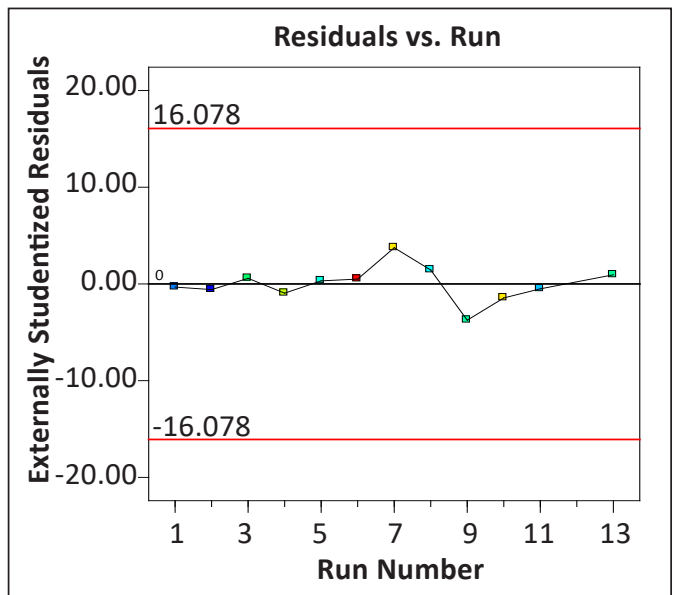

(b)

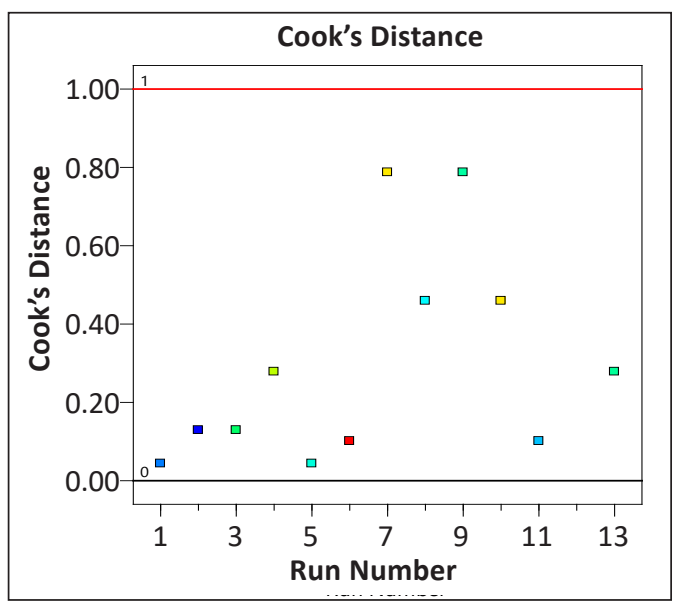

(d)

Figure 3. The Result of the Diagnoses for the Quadratic Model Approach 
point of the prediction and experimental response values just about the $45^{\circ}$ line. It specified that the proposed model was successfully identified the correlation of the input variables (catalyst concentration, reaction temperature, and reaction time) to the response (reaction conversion).

The model suitability was further determined by constructing a plot between the externally studied residuals and the prediction value. Figure 3(b) exhibits that all the data were under the limit, meaning that the model was suitable. As shown in Figure 3(c), all the leverage parameters were less than 1 . It denoted that there was no significant error that could affect the model approach. Figure 3(d) presents that all the points were under the expected Cook's Distance Parameter. It implied that there is no significant error in observation in taking the experimental data. All the results of the model diagnoses demonstrated that the quadratic model developed in this analysis was appropriate for FFA content and FFA conversion optimisation in the FFA esterification using a sulfuric acid catalyst. The graphical illustration, termed response surface, is frequently used to justify the individual and cumulative influences of the experimental variables and their successive effect on the response (Liu et al., 2014).

The significant variables affecting the FFA content and conversion were temperature and catalyst concentration as demonstrated in Figures 4 and 5. It can be observed that the FFA content reduced and, in contrast, the FFA conversion rose due to the temperature increase up to

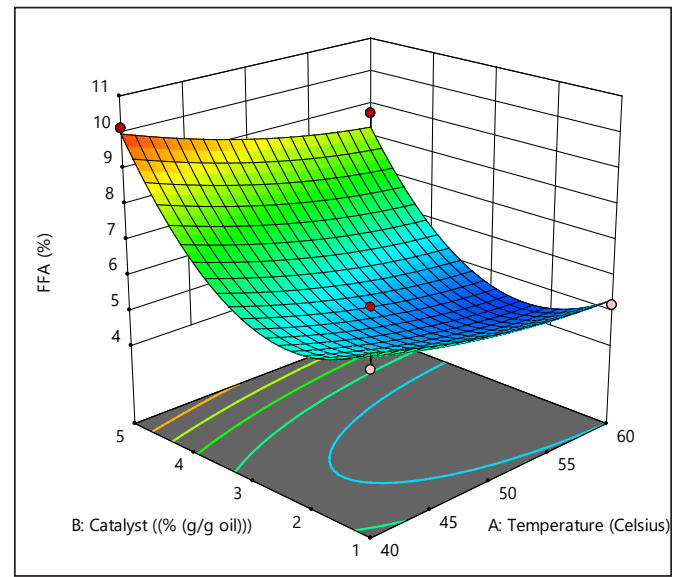

(a)

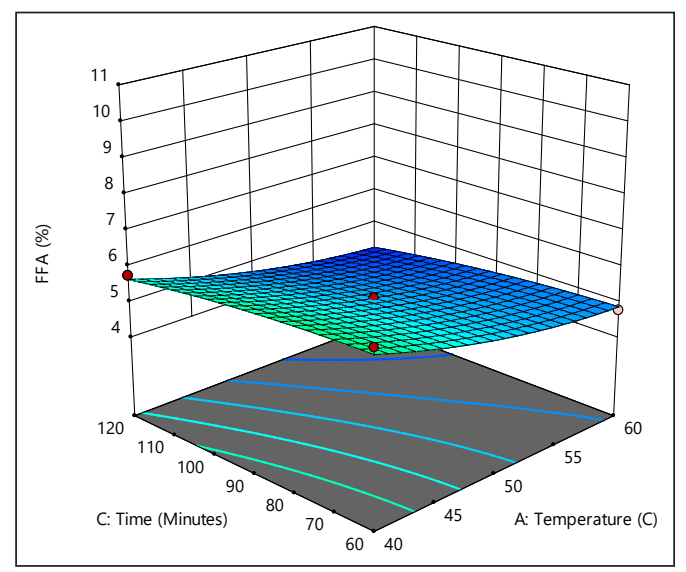

(b)

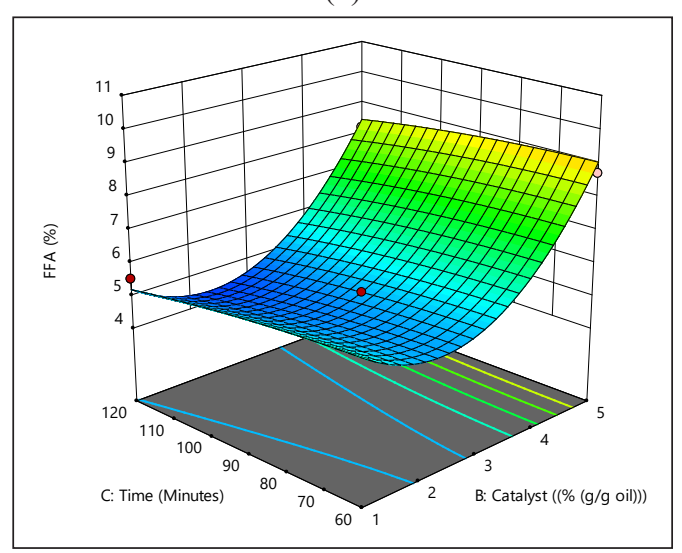

(c)

Figure 4. Three dimensional (3D) response surface of the effect of the process condition to the FFA content. (a) Reaction time $=90 \mathrm{~min}$; (b) Catalyst concentration $=5(\mathrm{~g} / \mathrm{g}$ RNSO) ; and (c) Reaction temperature $=50^{\circ} \mathrm{C}$. 
$60^{\circ} \mathrm{C}$. Additionally, increasing catalyst concentration from 1 to $3 \%$ significantly enhanced the FFA conversion and lowered the FFA content. However, an additional amount of catalyst employment did not result in the higher reaction conversion and the FFA removal. Reaction time considerably improved the reaction conversion and FFA removal from 0 to 60 minutes. After 60 minutes, reaction time slightly affected the esterification reaction.

In this work, the Derringer method was employed for the FFA conversion and FFA removal optimisation in the esterification using a sulfuric acid catalyst. In the complex system, various experimental variables have to be considered simultaneously to determine the optimum condition. It is known as a multi-response problem based on Multi-criteria Decision Making. In this case, the desirability approach is often employed as a vigorous instrument for optimisation in a multi-response system. The Derringer method is among the popular desirability method. The desirability function values are between 0 and 1 . The value 0 means that the factors provided an undesired response. On the other hand, the value 1 indicates the optimal condition of the parameter evaluated (Amdoun et al., 2018).

Based on the RSM simulation, it was revealed that the optimum conversion and the FFA content were $78.27 \%$ and $4 \%$, respectively, achieved at the reaction temperature of $59.09{ }^{\circ} \mathrm{C}$, catalyst concentration $1.98 \% \mathrm{~g} / \mathrm{g}$ RNSO, and reaction time of 119.95 minutes. At this operation condition, the value of the desirability ramp

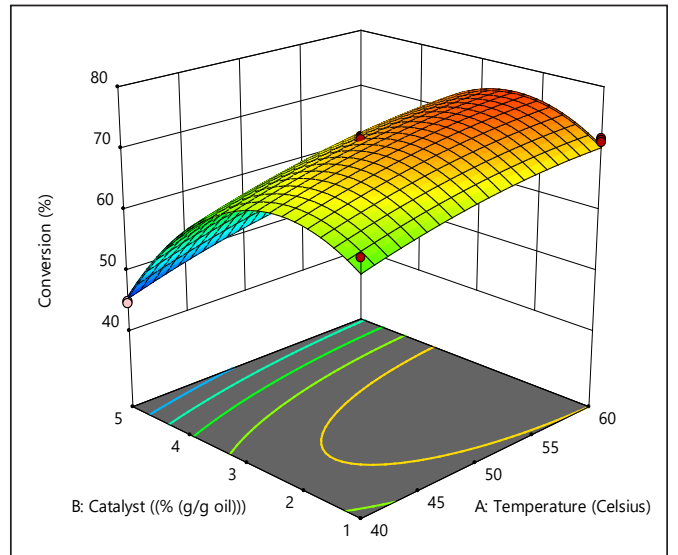

(a)

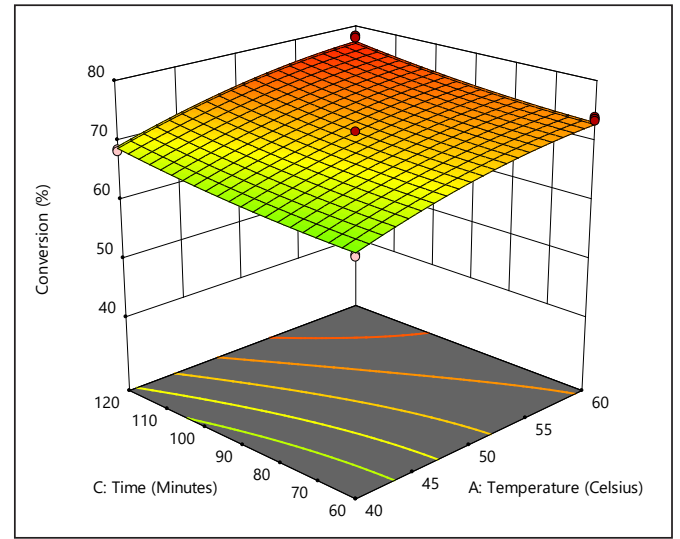

(b)

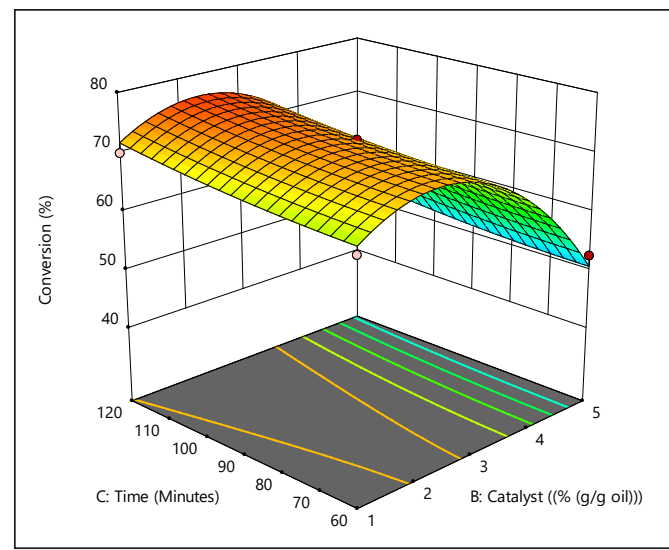

(c)

Figure 5. Three dimensional (3D) Response surface of the effect of the process condition to the FFA conversion. (a) Reaction time $=90 \mathrm{~min}$; (b) Catalyst concentration $=5(\mathrm{~g} / \mathrm{g}$ RNSO); and (c) Reaction temperature $=50^{\circ} \mathrm{C}$. 
was 1 (Figure 6). The result fitted the experimental data and indicated the accuracy of the model. A similar method of optimisation applying desirability function was also described by (Mourabet et al., 2017).

Extrapolation was performed using RSM to predict the operating conditions and achieve a maximum of $2 \%$ FFA content. As shown in Figure 7, the FFA content can be lowered up to $2 \%$ with the reaction condition as follows: reaction temperature, catalyst concentration,
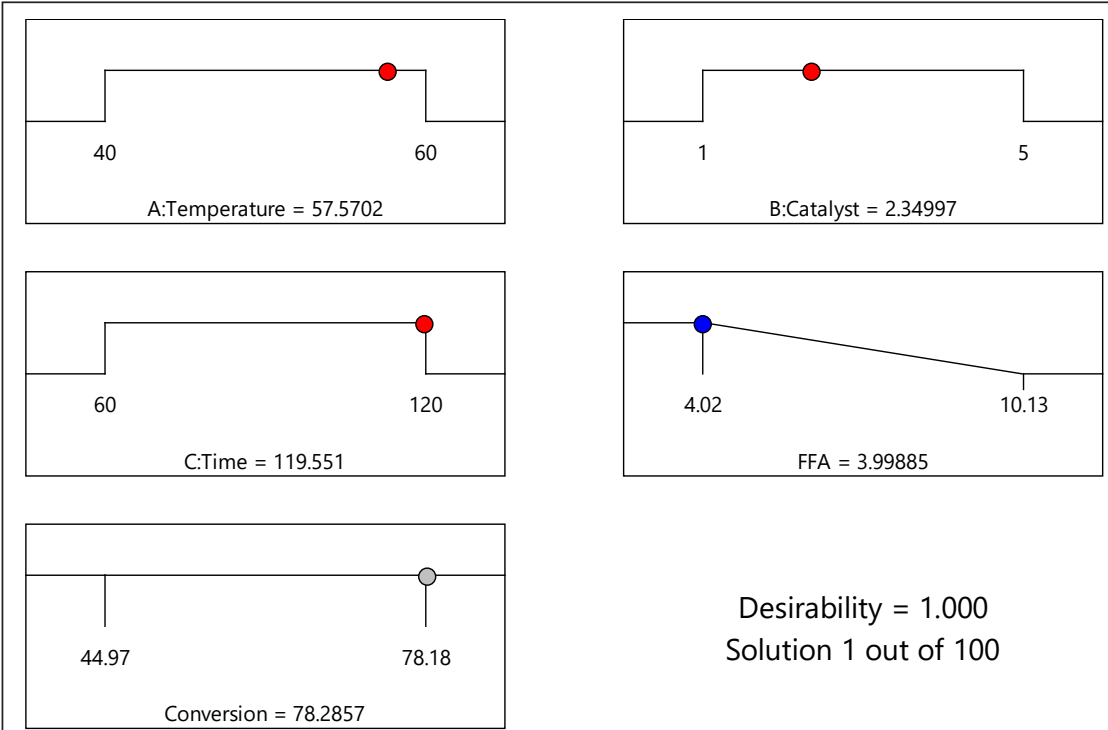

Desirability $=1.000$

Solution 1 out of 100

Figure 6. Optimisation of FFA conversion using RSM (Quadratic model)
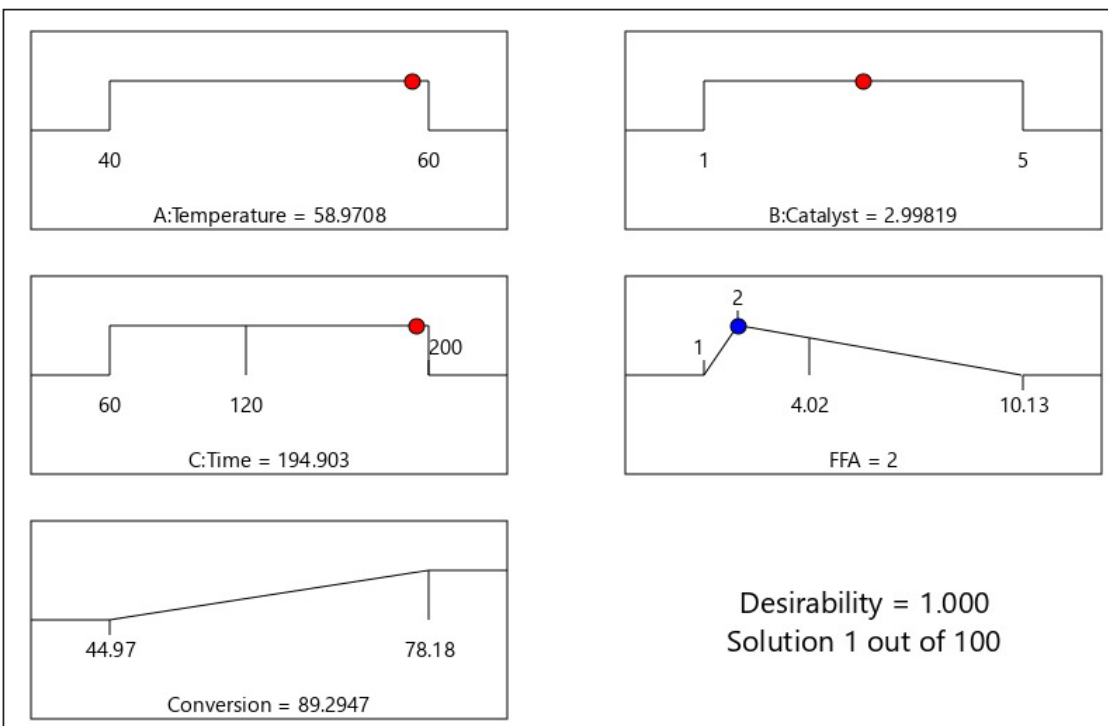

B:Catalyst $=2.99819$

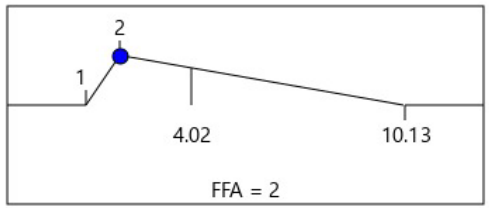

Desirability $=1.000$

Solution 1 out of 100

Figure 7. RSM prediction of operation condition on the FFA esterification using sulfuric acid catalyst to decrease the FFA content to $2 \%$ 
and reaction time were $58.97^{\circ} \mathrm{C}, 3 \%$, and 194.9 minutes, respectively, whereas the molar ratio of oil to methanol was fixed at 1:30. Therefore, the FFA conversion achieved was estimated at $89.3 \%$.

The result has shown that RSM is simple and effective for process optimisation. Furthermore, the RSM and desirability function combination lead to the more accurate finding of the optimal condition. The identical deduction was reported by Amdoun et al. (2018). This study is significant in providing the optimum operating condition for reducing the FFA in CNSO to fulfil the allowable level of FFA content before being used as feedstock for biodiesel production via base catalysed transesterification reaction.

\section{CONCLUSION}

The experimental work of FFA esterification in RNSO with methanol in the presence of sulfuric acid catalyst has shown the optimal reaction condition at the reaction temperature of $60^{\circ} \mathrm{C}$, a reaction time of 120 minutes, the molar ratio of RNSO) to methanol of $1: 30$, and the reaction times of 120 minutes, which yielded the reaction conversion of $78.18 \%$ and the FFA concentration of $4.01 \%$. This value did not match the maximum acceptable FFA content value for alkaline catalysed transesterification (2\%). The RSM was performed to estimate the optimal operation condition for achieving the FFA content of $2 \%$. The RSM model analysis demonstrated that the quadratic model was the most suitable for optimising this process in future work. The RSM extrapolation predicted that the FFA content of $2 \%$ could be obtained at the reaction temperature, catalyst concentration, reaction time of $58.97^{\circ} \mathrm{C}$, $3 \%$, and 194.9 minutes, respectively, and the fixed molar ratio of oil to methanol of $1: 30$.

\section{ACKNOWLEDGMENT}

The funding resource from the Research and Community Service Institute (LPPM) of Universitas Negeri Semarang through Collaborative Research Scheme (UNNES-UiTM Matching Grant) with Contract Number of 101.23.4/UN37/PPK.3.1/2020 is highly acknowledged.

\section{REFERENCES}

Aboelazayem, O., Gadalla, M., \& Saha, B. (2018). Biodiesel production from waste cooking oil via supercritical methanol: Optimisation and reactor simulation. Renewable Energy, 124, 144-154. https://doi.org/10.1016/j. renene.2017.06.076

Ahmad, A., Rehman, M. U., Wali, A. F., El-Serehy, H. A., Al-Misned, F. A., Maodaa, S. N., Aljawdah, H. M., Mir, T. M., \& Ahmad, P. (2020). Box-Behnken response surface design of polysaccharide extraction from Rhododendron arboreum and the evaluation of its antioxidant potential. Molecules, 25(17), Article 3835. https://doi.org/10.3390/molecules25173835 
Amdoun, R., Khelifi, L., Khelifi-Slaoui, M., Amroune, S., Asch, M., Assaf-ducrocq, C., \& Gontier, E. (2018). The desirability optimization methodology: A tool to predict two antagonist responses in biotechnological systems: Case of biomass growth and hyoscyamine content in elicited datura starmonium hairy roots. Iranian Journal of Biotechnology, 16(1), 11-19. https://doi.org/10.21859/ijb.1339

Aparamarta, H. W., Gunawan, S., Husin, H., Azhar, B., \& Aditya, H. T. (2020). The effect of high oleic and linoleic fatty acid composition for quality and economical of biodiesel from crude Calophyllum inophyllum oil (CCIO) with microwave-assisted extraction (MAE), batchwise solvent extraction (BSE), and combination of MAE-BSE meth. Energy Reports, 6, 3240-3248. https://doi.org/10.1016/j.egyr.2020.11.197

Arora, R., Toor, A. P., \& Wanchoo, R. K. (2015). Esterification of high free fatty acid rice bran oil: Parametric and kinetic study. Chemical and Biochemical Engineering Quarterly, 29(4), 617-623. https://doi. org/10.15255/CABEQ.2014.2117

Atabani, A. E., \& César, A. D. S. (2014). Calophyllum inophyllum L. - A prospective non-edible biodiesel feedstock. Study of biodiesel production, properties, fatty acid composition, blending and engine performance. Renewable and Sustainable Energy Reviews, 37, 644-655. https://doi.org/10.1016/j. rser.2014.05.037

Banani, R., Youssef, S., Bezzarga, M., \& Abderrabba, M. (2015). Waste frying oil with high levels of free fatty acids as one of the prominent sources of biodiesel production. Journal of Materials and Environmental Science, 6(4), 1178-1185.

Banchero, M., \& Gozzelino, G. (2018). A simple pseudo-homogeneous reversible kinetic model for the esterification of different fatty acids with methanol in the presence of Amberlyst-15. Energies, 11(7), Article 1843. https://doi.org/10.3390/en11071843

Chai, M., Tu, Q., Lu, M., \& Yang, Y. J. (2014). Esterification pretreatment of free fatty acid in biodiesel production, from laboratory to industry. Fuel Processing Technology, 125, 106-113. https://doi. org/10.1016/j.fuproc.2014.03.025

Corach, J., Sorichetti, P. A., \& Romano, S. D. (2017). Permittivity of diesel fossil fuel and blends with biodiesel in the full range from $0 \%$ to $100 \%$ : Application to biodiesel content estimation. Fuel, 188, 367-373. https:// doi.org/10.1016/j.fuel.2016.10.019

Dal Pozzo, D. M., Azevedo Dos Santos, J. A., Júnior, E. S., Santos, R. F., Feiden, A., Melegari De Souza, S. N., \& Burgardt, I. (2019). Free fatty acids esterification catalyzed by acid Faujasite type zeolite. RSC Advances, 9, 4900-4907. https://doi.org/10.1039/c8ra10248a

Demirbas, A. (2006). Biodiesel production via non-catalytic SCF method and biodiesel fuel characteristics. Energy Conversion and Management, 47(15-16), 2271-2282. https://doi.org/10.1016/j.enconman.2005.11.019

Dey, S., Reang, N. M., Das, P. K., \& Deb, M. (2021). A comprehensive study on prospects of economy, environment, and efficiency of palm oil biodiesel as a renewable fuel. Journal of Cleaner Production, 286, Article 124981. https://doi.org/10.1016/j.jclepro.2020.124981

Encinar, J. M., Nogales-Delgado, S., \& Sánchez, N. (2021). Pre-esterification of high acidity animal fats to produce biodiesel: Akinetic study. Arabian Journal of Chemistry, 14(4), Article 103048. https://doi. org/10.1016/j.arabjc.2021.103048 
Ratna Dewi Kusumaningtyas, Haniif Prasetiawan, Radenrara Dewi Artanti Putri, Bayu Triwibowo, Siti Choirunisa Furi Kurnita, Nanda Dwi Anggraeni, Harumi Veny, Fazlena Hamzah and Miradatul Najwa Muhd Rodhi

Gebremariam, S. N., \& Marchetti, J. M. (2018). Techno-economic feasibility of producing biodiesel from acidic oil using sulfuric acid and calcium oxide as catalysts. Energy Conversion and Management, 171(June), 1712-1720. https://doi.org/10.1016/j.enconman.2018.06.105

Ghasemian, S., Faridzad, A., Abbaszadeh, P., Taklif, A., Ghasemi, A., \& Hafezi, R. (2020). An overview of global energy scenarios by 2040: Identifying the driving forces using cross-impact analysis method. International Journal of Environmental Science and Technology, 1-24. https://doi.org/10.1007/s13762020-02738-5

Harun, F. W., Jihadi, N. I. M., Ramli, S., Hassan, N. R. A., \& Zubir, N. A. M. (2018). Esterification of oleic acid with alcohols over Cu-MMT K10 and Fe-MMT K10 as acid catalysts. In AIP Conference Proceedings (Vol. 1972, No. 1, p. 030025). AIP Publishing LLC. https://doi.org/10.1063/1.5041246

Islam, A., Taufiq-Yap, Y. H., Chan, E. S., Moniruzzaman, M., Islam, S., \& Nabi, M. N. (2014). Advances in solidcatalytic and non-catalytic technologies for biodiesel production. Energy Conversion and Management, 88, 1200-1218. http://dx.doi.org/10.1016/j.enconman.2014.04.037

Kusumaningtyas, R. D., Aji, I. N., Hadiyanto, H., \& Budiman, A. (2016). Application of tin(II) chloride catalyst for high FFA jatropha oil esterification in continuous reactive distillation column. Bulletin of Chemical Reaction Engineering \& Catalysis, 11(1), 66-74. https://doi.org/10.9767/bcrec.11.1.417.66-74

Kusumaningtyas, R. D., Akbar, M. H., \& Widjanarko, D. (2019). Reduction of FFA in kapok randu (Ceiba pentandra) seed oil via esterification reaction using sulfuric acid catalyst: Experimental and kinetics study. Jurnal Bahan Alam Terbarukan, 8(2), 156-166.

Kusumaningtyas, R. D., Handayani, P. A., Rochmadi, Purwono, S., \& Budiman, A. (2014). Tin(II)chloride catalyzed esterification of high FFA jatropha oil: Experimental and kinetics study. International Journal of Renewable Energy Development, 3(2), 7581. https://doi.org/http://dx.doi.org/10.14710/ijred.3.2.75-81

Kusumaningtyas, R. D., Prasetiawan, H., Pratama, B. R., Prasetya, D., \& Hisyam, A. (2018). Esterification of non-edible oil mixture in reactive distillation column over solid acid catalyst: Experimental and simulation study. Journal of Physical Science, 29(II), 212226. https://doi.org/10.21315/jps2018.29.s2.17

Lamas, D. L., Constenla, D. T., \& Raab, D. (2016). Effect of degumming process on physicochemical properties of sunflower oil. Biocatalysis and Agricultural Biotechnology, 6(March), 138-143. https:// doi.org/10.1016/j.bcab.2016.03.007

Liu, J., Wang, J., Leung, C., \& Gao, F. (2018). A multi-parameter optimization model for the evaluation of shale gas recovery enhancement. Energies, 11(3), Article 654. https://doi.org/10.3390/en11030654

Liu, W., Yin, P., Liu, X., \& Qu, R. (2014). Design of an effective bifunctional catalyst organotriphosphonic acid-functionalized ferric alginate (ATMP-FA) and optimization by Box-Behnken model for biodiesel esterification synthesis of oleic acid over ATMP-FA. Bioresource Technology, 173, 266-271. https://doi. org/10.1016/j.biortech.2014.09.087

Maran, J. P., \& Priya, B. (2015). Comparison of response surface methodology and artificial neural network approach towards efficient ultrasound-assisted biodiesel production from muskmelon oil. Ultrasonics Sonochemistry, 23, 192-200. https://doi.org/10.1016/j.ultsonch.2014.10.019 
Marchetti, J. M., \& Errazu, A. F. (2008). Esterification of free fatty acids using sulfuric acid as catalyst in the presence of triglycerides. Biomass and Bioenergy, 32(9), 892-895. https://doi.org/10.1016/j. biombioe.2008.01.001

Mourabet, M., El Rhilassi, A., El Boujaady, H., Bennani-Ziatni, M., \& Taitai, A. (2017). Use of response surface methodology for optimization of fluoride adsorption in an aqueous solution by Brushite. Arabian Journal of Chemistry, 10, S3292-S3302. https://doi.org/10.1016/j.arabjc.2013.12.028

Mubarak, M., Shaija, A., \& Suchithra, T. V. (2021). Experimental evaluation of Salvinia molesta oil biodiesel/ diesel blends fuel on combustion, performance and emission analysis of diesel engine. Fuel, 287, Article 119526. https://doi.org/10.1016/j.fuel.2020.119526

Murad, P. C., Hamerski, F., Corazza, M. L., Luz, L. F. L., \& Voll, F. A. P. (2018). Acid-catalyzed esterification of free fatty acids with ethanol: An assessment of acid oil pretreatment, kinetic modeling and simulation. Reaction Kinetics, Mechanisms and Catalysis, 123(2), 505-515. https://doi.org/10.1007/s11144-0171335-3

Musta, R., Haetami, A., \& Salmawati, M. (2017). Biodiesel hasil transesterifikasi minyak biji Nyamplung (Calophyllum inophyllum) dengan metanol [Biodiesel of the transesterification product of Calophyllum inophyllum seed oil from kendari using methanol solution]. Indonesian Journal of Chemical Research, 4(2), 394-401. https://doi.org/10.30598//ijcr.2017.4-rus

Ong, H. C., Milano, J., Silitonga, A. S., Hassan, M. H., Shamsuddin, A. H., Wang, C. T., Indra Mahlia, T. M., Siswantoro, J., Kusumo, F., \& Sutrisno, J. (2019). Biodiesel production from Calophyllum inophyllumCeiba pentandra oil mixture: Optimization and characterization. Journal of Cleaner Production, 219, 183-198. https://doi.org/10.1016/j.jclepro.2019.02.048

Paraschiv, S., \& Paraschiv, L. S. (2020). Trends of carbon dioxide $\left(\mathrm{CO}_{2}\right)$ emissions from fossil fuels combustion (coal, gas and oil) in the EU member states from 1960 to 2018. Energy Reports, 6, 237-242. https://doi. org/10.1016/j.egyr.2020.11.116

Rodríguez-Ramírez, R., Romero-Ibarra, I., \& Vazquez-Arenas, J. (2020). Synthesis of sodium zincsilicate $\left(\mathrm{Na}_{2} \mathrm{ZnSiO}_{4}\right)$ and heterogeneous catalysis towards biodiesel production via Box-Behnken design. Fuel, 280, Article 118668. https://doi.org/10.1016/j.fuel.2020.118668

Silitonga, A. S., Ong, H. C., Mahlia, T. M. I., Masjuki, H. H., \& Chong, W. T. (2014). Biodiesel conversion from high FFA crude jatropha curcas, Calophyllum inophyllum and ceiba pentandra oil. Energy Procedia, 61, 480-483. https://doi.org/10.1016/j.egypro.2014.11.1153

Taghizade, Z. (2016). Determination of biodiesel quality parameters for optimization of production process conditions. Polytechnic Institute of Bragança.

Veljković, V. B., Veličković, A. V., Avramović, J. M., \& Stamenković, O. S. (2019). Modeling of biodiesel production: Performance comparison of Box-Behnken, face central composite and full factorial design. Chinese Journal of Chemical Engineering, 27(7), 1690-1698. https://doi.org/10.1016/j.cjche.2018.08.002

Widiarti, N., Suryana, L. A., Wijayati, N., Rahayu, E. F., Harjito, H., Wardhana, S. B., Prasetyoko, D., \& Suprapto, S. (2017). Synthesis of $\mathrm{SrO}_{\mathrm{SiO}}$ catalyst and its application in the transesterification reactions of soybean oil. Bulletin of Chemical Reaction Engineering \& Catalysis, 12(2), 299-305. https://doi. org/10.9767/bcrec.12.2.804.299-305 
